\title{
Capital Markets Union and the fintech opportunity
}

\author{
Maria Demertzis, Silvia Merler and Guntram B. Wolff
}

MARIA DEMERTZIS (maria. demertzis@bruegel.org) is the Deputy Director of Bruegel

SILVIA MERLER (silvia. merler@bruegel.org) is an Affiliate Fellow at Bruegel

GUNTRAM B. WOLFF (guntram.wolff@bruegel. org) is the Director of Bruegel

The authors are grateful to André Sapir and Nicolas Véron for comments on an earlier draft. Inês Gonçalves Raposo provided excellent research assistance. The paper was prepared for and presented at the informal ECOFIN in Tallinn, Estonia, on 15 September 2017.

\section{Executive summary}

COMPLEMENTING EUROPE'S BANK-BASED system with deeper capital markets and more cross-border financial integration promises benefits, but despite long-running debate and policy action, financial system change remains slow.

FINTECH HAS THE potential to change financial intermediation structures substantially. It could disrupt existing financial intermediation with new business models empowered by intelligent algorithms, big data, cloud computing and artificial intelligence. Lower costs and potentially better consumer experiences could be the driving forces.

HOWEVER, EMPIRICALLY, FINTECH remains at a small scale, especially in the European Union. Even the largest fintech market, in China, is of marginal size compared to overall financial intermediation. In the EU, much of fintech is concentrated in the United Kingdom.

WE ARGUE THAT policymakers need to consider four questions urgently: (1) Develop a European or national fintech market? (2) What regulatory framework to pursue? (3) Should supervision of fintech be exercised at the European level? (4) What is the overall vision for the EU's financial system? Getting the answers to these questions right at an early stage of market development would be an opportunity to shape a stable and cost-efficient financial system. In contrast, late action could mean that Europe loses out to foreign competitors and misses an opportunity to improve financial intermediation in Europe.

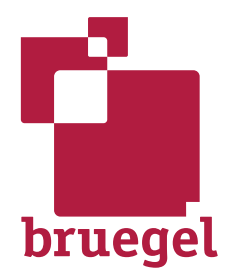




\section{Introduction}

Capital markets union (CMU) is a flagship EU initiative to strengthen capital markets in the EU. The expression was first used by European Commission president-elect Jean-Claude Juncker when outlining his policy agenda in mid-2014 (Juncker, 2014). A recent mid-term review of the CMU project called for reinforced action, including accelerated action by EU member states (European Commission, 2017).

Complementing Europe's bank-based system with both deeper capital markets and more cross-border financial integration promises benefits ${ }^{1}$. Deeper capital markets that diversify the financial system and reduce its reliance on banks are empirically less prone to financial crises, and can also be associated with higher growth (Langfield and Pagano, 2016). Greater cross-border integration has the benefit of increasing the size of markets, enabling more liquidity and efficiency. Integration can also increase cross-border risk-sharing, in particular if cross-border equity ownership increases. Empirical studies show that deep and integrated capital markets can play a significant role in absorbing country/state-specific shocks (Allard et al, 2013).

Despite long-standing debate, the financial intermediation landscape in Europe is changing slowly and remains dominated by traditional banking. The 'Lamfalussy' report in 2001, for example, highlighted that the EU could gain from constructing integrated financial markets; some of the report's recommendations on European securities markets - such as the 'single prospectus' - are still being discussed (European Commission, 2001). The Lamfalussy process has been successful in delivering a certain degree of harmonisation of European capital markets, most notably in form of the 'MIFID' directive (2014/65/EU) that provides harmonised regulation for investment services across the 31 member states of the EEA. Nevertheless, the EU's financial landscape (excluding the UK) appears to have changed very little since 2014 (see Figure Al in the annex) ${ }^{2}$.

There are many reasons why financial system change is slow. Financial systems typically have a long history and their eventual shape is a result of entrepreneurial and policy decisions taken in the distant past. Their shape is influenced by the regulatory and supervisory landscape. Often, the regulatory and supervisory system is suited particularly to the incumbents. There are also often deep connections between key financial system players and the political system (Véron, 2017). Similarly, household financial decisions are persistent and reflect attitudes that are deeply ingrained. For example, the savings habits of EU households differ substantially from those of US households, with consequences for the shape of the financial system. For example, equity plays a smaller role in Europe as an instrument of choice for savings ${ }^{3}$. Making changes to financial system structures is thus a long-term policy challenge.

However, two ongoing developments have the potential to significantly alter Europe's financial system: Brexit and 'fintech.' On Brexit, much will depend on the final agreement but as the situation currently stands, financial institutions have started to adapt. The policy challenge on the EU side will be to (a) prevent regulatory and supervisory arbitrage within the EU, and (b) ensure continued access to all desirable financial services. The former is particu-

1 The changing policy view was, for example, highlighted and promoted in a note by one of the authors to the informal ECOFIN (Sapir and Wolff, 2013) in September 2013 in Vilnius, and a speech by the European Central Bank president (Draghi, 2014).

2 The role of banks has somewhat declined since 2010 but with it so has the overall size of financial intermediation. The UK has a much larger financial system and especially its equity markets are much larger. In the US, by contrast, the banking sector is much smaller while the overall size of the financial system is comparable to that of the EU. Finally, China, to an even greater extent than Europe, is dominated by banks while Japan is characterised by a strong bond market.

3 It is debatable whether it is because of preferences or because of missed opportunities and actual obstacles that EU households hold significantly larger parts of their financial portfolio in deposits than US households. The composition of the financial wealth of households is however changing. Compared to 2011, the relative importance of deposits has declined in the EU while equities have gained in importance (Figure A2, annex). We need to recognise also significant differences in this respect between countries. 
larly important as there is a move from a system in which EU capital markets were concentrated in London and largely supervised by UK authorities ${ }^{4}$, to a more dispersed system across the EU. We recommend in that context that the role of the European Securities and Markets Authority (ESMA) be significantly strengthened (Sapir et al, 2017).

Fintech is the label for new technology-enabled businesses that disrupt the market for financial services. Fintech has been much discussed in the last few years ${ }^{5}$ but the policy debate is still in its infancy and the scope of fintech is not understood by all in the same way. To start with, there is no universal definition of fintech. In the broadest sense, it is the use of innovative information technology in financial services. The main segments of the fintech universe are: (1) alternative financial intermediation including peer-to-peer (P2P) and alternative lending and crowd-funding; (2) payment systems and transfers; (3) personal finance such as robo-advising; and (4) insurance. Statistics on fintech are still not as comprehensive and homogeneous as those on the traditional banking sector, complicating comparisons.

The fintech sector has the potential to improve financial intermediation and to disrupt established financial intermediaries. It promises to reduce the cost of financial intermediation ${ }^{6}$ by screening clients and better assessing creditworthiness, improving access to finance, and thereby ultimately benefiting productivity. Fintech also has the potential to change the 'user experience.' The enablement of fintech is to a great extent down to the availability of computer power, intelligent algorithms, availability of massive amounts of data and mobile storage through the cloud, and mobile hardware that provides constant accessibility. Whether fintech will harness that potential depends on numerous factors, including consumer preferences and adaptability, the regulatory framework, the reactions and attitudes of incumbents and the political choices that will help (or not) to create a credible alternative to current ways.

More specifically, fintech can disrupt banks and capital markets and their relative positions. In broad terms, we can classify financial intermediation as consisting of banks and capital markets. The core business of the former is maturity transformation by collecting shortterm deposits and lending long-term. Capital markets, in turn, consist of stocks and bond markets, derivatives and, more broadly, clearing, settlement and payment systems. There are numerous overlaps between the two. For example, banks and other actors offer transaction services to households so they can invest their savings in stocks. The stock exchange itself is not only the marketplace organiser for trading but also provides transaction services. New fintech business models combined with new technologies have the potential disrupt the banks offering the service, the transaction service provider and the marketplace organiser. Each of these players will respond to the new players by adapting, competing and taking them over. This could fundamentally change the shape of financial intermediation. In sum, the fintech transformation could affect the entire financial intermediation chain.

The fintech challenge is to foster 'good' disruption while preventing 'bad' disruption. Any major technological innovation combined with a viable business model has the potential to disrupt established companies by providing better services. It can also bypass regulation that is primarily intended to protect the incumbents. However, it can also bypass useful regulation. Thus, disruption could be harmful if its profitability is a result of arbitrage against useful and perhaps even systemically important regulation. In the transport sector, for example, some regulation provides safety to customers and workers but other regulation essentially protects quasi-monopolies. Ride-sharing platforms, by disrupting the sector, can provide great benefits to consumers and improve opportunities for drivers. However, they might also disrupt useful customer safety regulation or employment standards. Similar issues can arise in fintech (see section 3$)^{7}$.

4 Sapir et al (2017) estimate that 90 percent of the EU wholesale financial market is undertaken in London.

5 See DNB (2016) for an overview.

6 For example, Philippon (2016) argues that the current financial system is rather inefficient and that the unit cost of financial intermediation has only marginally decreased.

7 Philippon (2016) argues that fintech if properly regulated from the beginning has the potential to become a low-leverage financial system with trading systems that are cheap, transparent and open access. 


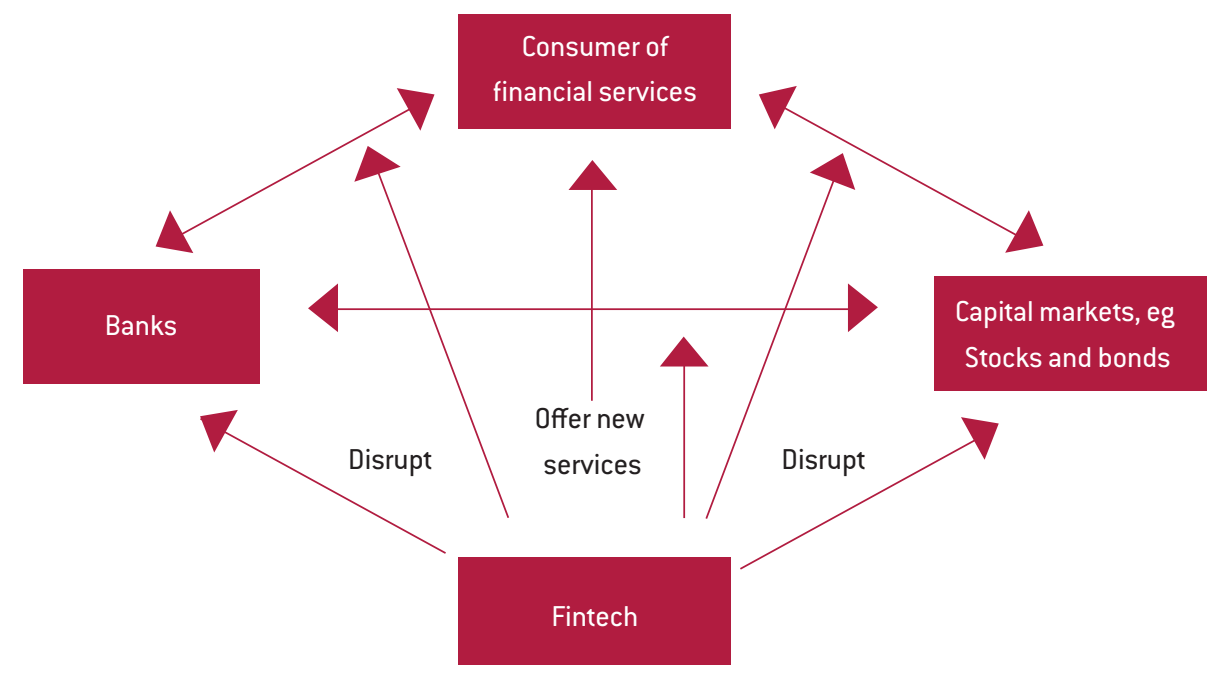

Source: Bruegel.

In the EU context, the important question is whether fintech can disrupt Europe's financial system in a way that promotes CMU, helps integrate the financial system across borders and increases its stability and efficiency. European financial ecosystems have grown over centuries within national and even regional borders. As the fintech sector disrupts this system, the question will be whether it does so at the EU level or whether the disruption will again follow national patterns. In other words, will fintech companies immediately harness the benefits of the entire European single market in capital markets and also banking, or will their activities and scaling-up happen at national levels? The issue of scaling-up might be decisive for whether the EU will actually be able to develop a fintech sector that can be of global relevance.

\section{Fintech in perspective}

The current levels and growth rates of fintech give an indication of its potential to help develop EU-wide capital markets. Comparisons with other continents can provide insights in terms of the emerging global trends. We also discuss the different fintech segments.

\subsection{The economic significance of fintech}

In all major jurisdictions, the volume of alternative finance is very small compared to the size of capital markets ${ }^{8}$. Even in China, which does not yet have a mature capital market while leading on fintech, the volume of alternative finance amounts to only 0.2 percent of the size of the capital markets. In all jurisdictions, the growth rate of fintech has exceeded that of

Comparable and comprehensive data on fintech is not readily available from the traditional sources of financial statistics. Mapping the current landscape requires merging information from different sources, being aware that different statistical definitions might be being used. Our main source for this paper is the Cambridge Centre for Alternative Finance for the lending and crowdfunding activities, but we also rely on individual country sources, when needed. For instance, a good overview for the German fintech market is provided by Schmitt and Weber (2016). 
capital markets (Figure 3). In the US, where the capital market is the largest and most mature, the capital market expanded by only 1 percent in 2015, compared to a 248 percent growth in alternative finance. In China, capital markets expanded by 15 percent in 2015, while fintech volumes almost quadrupled. In the UK and more so in the rest of the EU, capital markets actually shrank in 2015, which is certainly not good news in the context of the CMU objective. Fintech expanded in the same period, but at much slower rate than in the US or China.

Figure 2: Size of Fintech and financial intermediation (including banking, stocks and bonds] in US, China, EU excl. UK and UK, 2015 [ $\$$ billions]

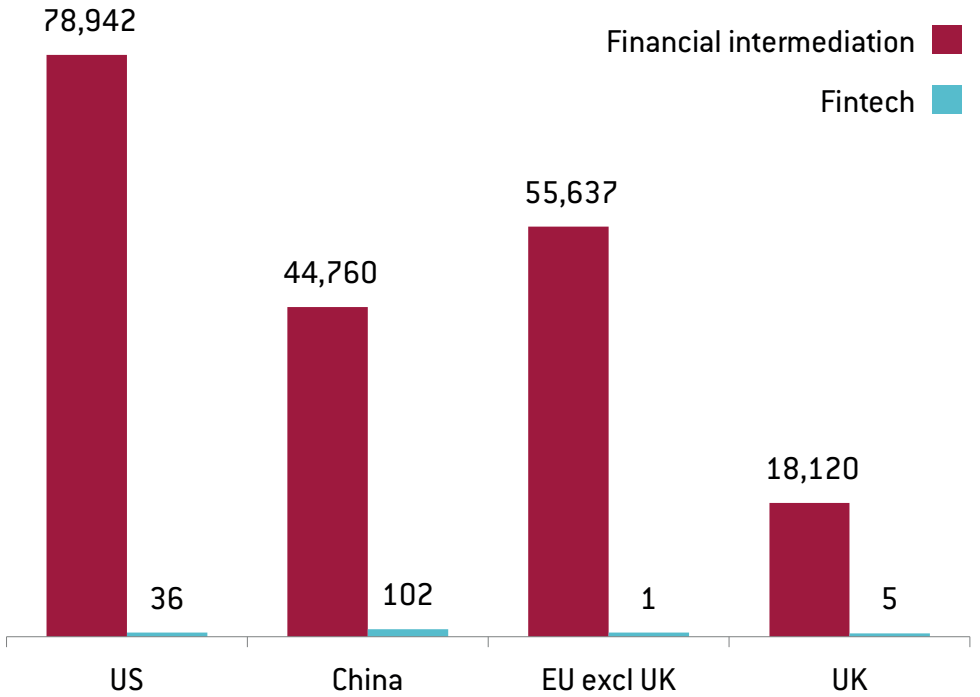

Source: Cambridge Centre for Alternative Finance (2016). For sources on financial intermediation, see the notes to Figure A1 in the annex.

Fintech has grown globally over the past five years, but there are significant differences in different jurisdictions, with China in the lead. China leads in terms of both alternative finance volumes and growth rates, followed by the US. In China, the alternative finance market was worth almost $\$ 102$ billion in 2015, having more than tripled in one year.

Figure 3: Average growth rates of fintech in the US, China, EU excl. UK, UK [\%], 2014-15

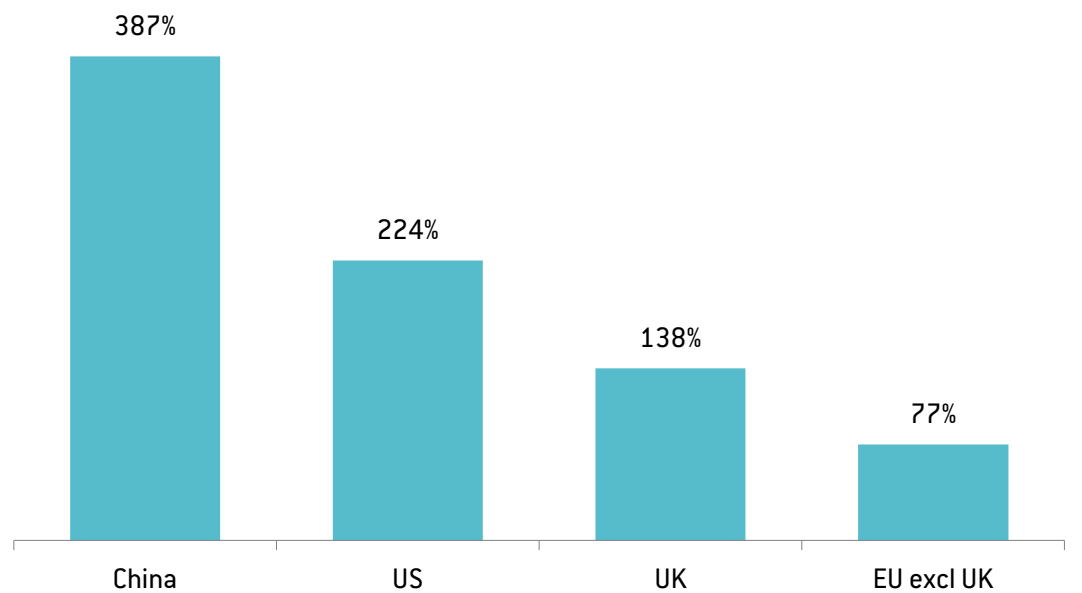

Sources: Bruegel based on Cambridge Centre for Alternative Finance (2016). Note: Fintech as expressed here encompasses all lending and crowdfunding activities reported by the Cambridge Centre for Alternative Finance. For a taxonomy of included categories, see Cam bridge Centre for Alternative Finance (2016). Average growth rates have been computed over the last two years of available data, 2015 and 2014. 
In different European countries, the fintech market remains very small. If we exclude the UK, the total volume of alternative finance in the EU was $\$ 1$ billion in 2015, and compared to 2014 the growth rate was less than 100 percent (Cambridge Centre for Alternative Finance, 2016). Within Europe, France and Germany are leading (Figure 4). Volumes are very low in central and eastern European countries and other countries, although growing fast.

Figure 4: Fintech market volumes in Europe 2013-15 [€ millions]

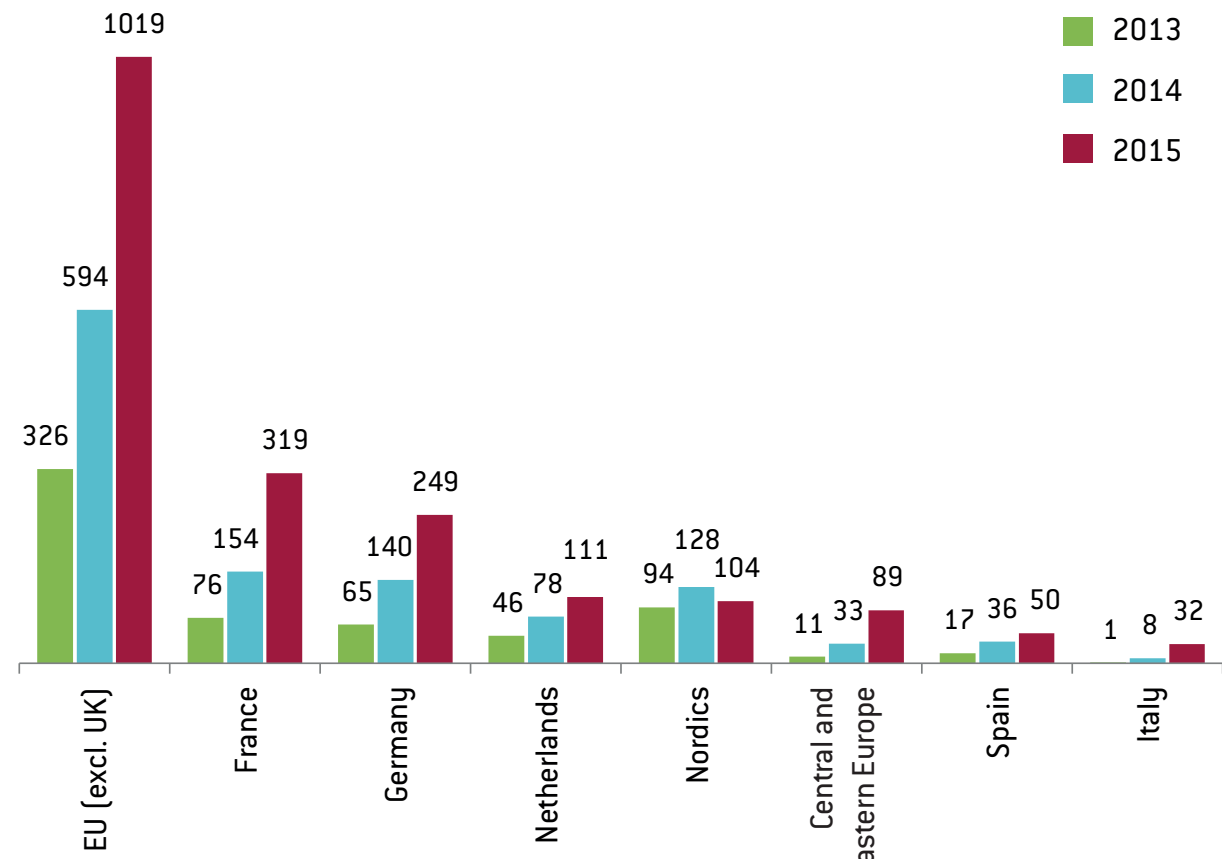

Source: Cambridge Centre for Alternative Finance [2016]. Notes: 1. Fintech as expressed here encompasses all lending and crowdfunding activities reported by the Cambridge Centre for Alternative Finance. For a taxonomy of included categories, see Cambridge Centre for Alternative Finance (2016) 2. EU excluding the UK includes the following non-EU countries - Albania, Armenia, Belarus, Bosnia \& Herzegovina, Georgia, Kosovo, Macedonia, Moldova, Montenegro, Serbia, Ukraine, Iceland, Russia, Norway and Turkey. The distinction of EU from non-EU countries is not possible given data availability restrictions. However, the size of the outside of the EU countries is deemed to be low given the small number of surveyed platforms in these countries.

Fintech also refers to the actions of large digital companies (techfin) ${ }^{9}$, which are not covered in the data presented here. Big players such as Amazon, Apple or Google are already active in fintech. The number of users of alternative payment systems such as Apple Pay, Samsung or Android Pay has also been increasing steadily since 2015, rising from 18 million in 2015 to 144 million in the first half of 2017. Apple Pay leads with 86 million customers, but Samsung Pay and Android Pay are catching up quickly, having expanded their customer base at a 1000 percent growth rate in two years (from 3 and 2 million users in 2015 to 34 and 24 million, respectively) (Juniper Research, 2017).

A more decisive entry into the fintech market by the big internet companies could hugely change the fintech world and financial intermediation globally, in particular because of the access these companies have to data. When 'fintech' meets 'techfin' there is great potential for financial intermediation globally to be challenged. The big internet players are not only active in payment systems. In June 2017, for example, Amazon announced that Amazon Lending had surpassed $\$ 3$ billion in loans to small businesses since the service launched in 2011, reaching more than 20,000 small businesses ${ }^{10}$. Financial intermediation is, to a significant

9 'Fintech' covers financial intermediaries whereas 'techfin' covers data intermediaries (like Google) that aim to tap the financial intermediation market. See Zetzsche et al (2017).

10 See Amazon's press release http://phx.corporate-ir.net/phoenix.zhtml?c=176060\&p=irol-newsArticle\&ID=2279738. 
extent, about overcoming information asymmetries. Large internet firms have databases and intelligent algorithms which in principle give them significant information on both potential borrowers and lenders. Whether and how that data can be used and whether its information content is already superior to the information held by banks is a question for debate. It is also an issue for debate to what extent financial regulation poses obstacles to internet firms. Evidence so far indicates that large internet firms have not yet entered the fintech market on a big scale. The potential for disruption could, however, be significant and potentially more significant than that arising from the smaller players discussed above as they can more easily become integrated into established financial institutions ${ }^{11}$.

Fintech activities in Europe are still largely domestic. A key measure of whether fintech can be instrumental in constructing CMU and an integrated banking market - one of the aims of banking union - is the degree of internationalisation of these activities, ie whether they are mostly national or have a relevant EU cross-border dimension. Measuring cross-border transactions is challenging, so we can only offer preliminary evidence based on a survey conducted by the Cambridge Centre for Alternative Finance. Cross-border activity can be measured in terms of inflow funds (investor funding coming from outside a platform's home country) or outflow funds (investor funding leaving the platform's home country). In terms of inflows, nearly 50 percent of surveyed platforms had no funding from other countries; in terms of outflows, 76 percent of fintech reported no cross-border activities in $2015^{12}$. Overall, this data suggests that fintech activities in Europe are still largely domestic.

\subsection{The different fintech segments}

Alternative lending in the EU is dominated by P2P consumer lending and crowdfunding. Excluding the UK, the leading countries for P2P consumer lending are Germany, France and Finland. $\mathrm{P} 2 \mathrm{P}$ business lending, which is prominent in China, plays a more limited role in the EU. France was the largest market for crowdfunding in the EU in 2016, followed by the Netherlands, Italy and Germany. Most of the EU crowdfunding was in the form of debt crowdfunding. The number of crowd-funding platforms in EU countries increased very significantly from 2014 to $2016^{13}$.

Payment systems and digital currencies are another important area of fintech development and have experienced rapid increases in market capitalisation. Digital currencies or cryptocurrencies are currency systems in which encryption techniques regulate the generation of units of currency and blockchain (see description in the annex) is used as the decentralised technology to verify transfers of funds. The combined market capitalisation of all cryptocurrencies has increased steadily since 2014, reaching \$112 billion in August 2017 (Table 1 in the annex) ${ }^{14}$. Meanwhile, there is also an increase in payment and settlement systems based on blockchain technology that provide greater transparency reducing the risk of this technology to be misused by criminal activity.

Payment companies generally act as gateways between users of cryptocurrencies and the broader economy, bridging national currencies and cryptocurrencies. A recent survey shows that in Europe, users seem to be mostly interested in the two kinds of payment services: merchant services, which process payments for merchants that accept cryptocurrency, and general-purpose cryptocurrency platforms, which perform a variety of cryptocurrency transfers ${ }^{15}$.

11 Zetzsche et al (2017) raise the significant legal challenges that the rise of techfin poses.

12 Source: Cambridge Centre for Alternative Finance (2016), p45; Note: encompasses lending and crowdfunding.

13 ESMA (2017a), Chart 1.

14 Miners play a crucial role in cryptocurrency systems, as they are responsible for adding new blocks to the global ledger. Cumulative mining revenues surpassed $\$ 2$ billion in 2016, but mining is a geographically very concentrated activity. Almost three-quarters of major mining pools are based in two countries; 58 percent of mining pools with greater than 1 percent of the total bitcoin hash rate are based in China, followed by the US with 16 percent. In part, concentration is due to physical needs: a cryptocurrency mining facility requires low-cost electricity, fast internet connection and low environmental temperature to keep the mining equipment from overheating (Hileman and Rauchs, 2017).

15 Unlike mining activities, payment companies are geographically very dispersed (Hileman and Rauchs, 2017). 
Robo-advice can expand access to financial services to previously under-serviced clients, and can improve on human advice. It is still small-scale in Europe and consumer protection needs to be taken into account in future developments. Robo-advice encompasses algorithm-based online services ranging from financial advice, portfolio management or contract brokering across the securities, banking and insurance sectors ${ }^{16}$. The Financial Stability Board (2017) highlights the main benefits of robo-advising as improved access and convenience of financial services, reduced information asymmetries, more stock market participation by private households and more competition for incumbents resulting in reduced costs.

While promising, robo-advising is still at a development stage, particularly in Europe. Assets under management (AuM) in Europe amount to only 5-6 percent of those in the United States (Kaya, 2017). In Europe, there is evidence of very high growth rates but of a small magnitude relative to traditional players ${ }^{17}$. The scope for growth might be limited given consumer preferences: approximately two in five (36 percent) of European respondents to an ING Groep International Survey on Mobile Banking rejected outright the possible use of automated financial activities and 26 percent were willing to use this type of platform to make decisions as long as decisions are subject to final approval by the customer (ING, 2017). Legal, security and operational aspects - including consumer protection - are bound to be an issue in the future development of this technology. The European supervisory authorities (ESAs) do not see a need for supervisory action at present. The European Parliament (2017) underlined that the same consumer protection requirements should apply to robo-advice as to face-to-face advice. Others argue that it is sufficient that the use of robo-advice improves on imperfections of the current human advisors, such as misaligned incentives ${ }^{18}$.

The insurance sector is subject to similar pressures from technology. The use of new technologies such as big data, artificial intelligence or blockchain might pressure traditional incumbents to change their business models and/or seek collaboration ${ }^{19}$ but the InsurTech sub-sector has still to mature and faces similar regulatory and safety challenges to the others $^{20}$. Data on InsurTech activity in the EU is particularly scarce but there is some evidence of recent growth in activity ${ }^{21}$.

Overall, data quality and availability on fintech is low, but several preliminary conclusions can be drawn. Fintech is still small in comparison to the size of capital markets and is also significantly smaller in Europe than in the US or China, and this is especially the case in the EU if we exclude the UK. Fintech in Europe is also growing significantly more slowly than elsewhere. Although limited, the evidence suggests that fintech is still a predominantly domestic activity, with limited cross-border flows. The fintech sector in the EU does not appear to scale at the European level, in contrast to fintech, for example, in China, where new alternative finance services often spread quickly to several hundred millions of customers. Big internet companies have not yet decisively entered the fintech market, but their arrival could quickly change the overall picture.

16 These services are (so far) usually aimed at tech-savvy users, typically a younger clientele with fewer assets, and can be offered either by innovators or, more recently, by large incumbents. Huddlestock and Shareville are examples of stand-alone firms. For incumbents offering automated advice, see the case of Wells Fargo in the US.

17 See for instance the case of Germany, as documented by Schmitt and Weber (2016): "In 2015, robo-advisors in Germany had $€ 170$ million of AuM. This amounts to less than 0.01 percent of AuM of the German open-ended funds industry. Up to the end of 2015, intermediated assets of robo-advisors operating in Germany have grown at a CAGR of 1200 percent".

18 See Philippon (2016) and Bergstresser et al (2009).

19 Cermeño (2016). An example of collaboration is Allianzx, a venture unit of Allianz Group partnering and investing in insurtech start-ups.

20 The European Parliament (2017) notes the "considerable regulatory uncertainty around InsurTech, and stresses that this needs to be addressed so as to ensure security, privacy, fair competition, and financial stability"

21 Nearly half of the current InsurTech businesses entered the German market in 2015 (Schmitt and Weber, 2016). 


\section{Implications and policy conclusions}

The question is whether Fintech will disrupt the financial system in a way that will decrease or increase undesirable properties. There is a fairly broad agreement that high leverage, opacity and complexity were major contributors to the recent financial crisis.
Fintech can profoundly change financial intermediation in its current form, by lowering the cost of financial intermediation. In general, fintech promises to provide financial intermediation at a lower cost and to a greater number of customers, who might currently not be included. A substantial body of work has shown that the cost of financial intermediation has hardly changed and remains quite high, suggesting that significant cost-saving opportunities exist (Philippon, 2016). At a deeper level, fintech's potential derives from the use of technology to more directly match savers and investors and overcome information asymmetries more effectively by the efficient use of large amounts of data. The use of digital currencies could challenge the role of traditional bank deposits. Digital central bank money, in turn, could put into question fractional reserve banking and shift the financial system towards narrow banking ${ }^{22}$.

Fintech can also profoundly change financial intermediation by providing different products and offering different consumer experiences. The availability of financial products via user-friendly mobile apps could change the way consumers and especially households use financial products. For example, providing payments by simply sending an email could reduce reliance on cash. In China, apps already allow users to invest in stocks or in crowd-funding products with a simple click $^{23}$. If it becomes much easier to invest in equity, some European households could decide to shift their savings from deposits to readily available stock portfolios. Better and automatic monitoring of price developments in financial products through robo-advising could further lower thresholds for consumers to gradually shift away from traditional banking and traditional financial products to fintech ${ }^{24}$.

The question is whether Fintech will disrupt the financial system in a way that will decrease or increase undesirable properties. There is a fairly broad agreement that high leverage, opacity and complexity were major contributors to the recent financial crisis. There is also a substantial policy discussion on the problem of systemically important banks and the idea that their too-big-to-fail status provides them with unwarranted rents. Some have argued that the real opportunity of fintech might be its potential to transform the financial system towards one with lower leverage, while decreasing the cost of financial intermediation (Philippon, 2016). But this will depend on the regulatory system, on supervision, future technological developments, business plans and politics. The Financial Stability Board (FSB) has analysed the implications of the current fintech sector and has not found a reason to worry about financial stability at this stage, in particular since fintech remains small in size (Financial Stability Board, 2017). The FSB does point out, however, that operational risks and cyber risks need to be monitored carefully. It also points to the need to monitor macro-financial risks, as they could emerge if left unattended.

To date, Fintech has contributed little to European financial market integration but it could become more important. The evidence presented in this paper suggests that fintech currently lacks the scale and internationalisation that would enable it to make a difference, but the situation could change if big players were to enter the market. Moreover, greater scaling will be facilitated by creating the conditions for Fintech companies to offer new business propositions in all EU countries. Fintech, especially peer-to-peer business

\footnotetext{
22 See for example Broadbent (2016).

23 See for example The Economist (2017).

24 Hach and Steger (2016) report that fintech entrepreneurs see their market position expanding in the future, but without replacing traditional financial institutions. The segments of investing and asset management, payments and crowdfunding/lending are perceived as the most promising. A strong increase in market revenue by 2020 is expected by 66 percent of the respondents. Curiously, the same share of the respondents ( 66 percent) reportedly do not believe that fintech will replace traditional financial institutions.
} 
lending and some types of crowdfunding, could become more quickly relevant in some parts of the market ${ }^{25}$.

So overall, the significance of Fintech for European financial markets over the next 10 years is difficult to gauge because its impact depends on consumers, technology, business decisions and also on regulators. In our view, European policymakers need to consider four issues in particular:

\section{Issue 1: Should fintech markets be European or national?}

The first question is whether European policymakers would like to encourage European or national fintech markets. Harvesting the full potential of fintech will require scale and the fintech industry will likely only become significant in Europe if it can scale-up across the entire EU/EEA. At the same time, there may be some reasons to promote local fintech markets. For example, crowd-funding might in some circumstances best work at city level ${ }^{26}$. Also, there may be substantially different preferences across EU countries, for example as concerns consumer lending, which stand in the way of creating a single European market. In contrast, a European market would allow companies to scale, which in turn would increase their global competitive position.

If the aim is an integrated European fintech capital market, fragmentation of fintech along national lines should be kept to a minimum and a European framework should be developed ${ }^{27}$. Currently, EU fintech, especially for the EU without the UK, still mostly operates in a national context, and cross-border service provisioning is weak. For example, there are fintech scenes in Berlin or Paris but often their business models are focused on the national markets. This is in part because regulation is defined and enacted at national level ${ }^{28}$. ESMA (2017) notes that regulations on crowd-funding are national and implemented at the national level. EBA (2017) documents the breakdown of fintech firms by regulatory status.

Accelerating the regular CMU agenda will be of great importance also to fintech. Shifting financial intermediation towards capital markets and increasing cross-border integration will require action on multiple fronts, including increasing the transparency, reliability and comparability of information and addressing financial stability concerns. Some quick wins might be available, but the CMU's real potential can only be achieved with a longterm structural policy agenda. A first key reform could be more integrated accounting enforcement and supervision of audit firms ${ }^{29}$. More complex issues such as corporate credit information, financial infrastructure, insolvency, financial investment taxation and the retrospective review of recent capital markets regulation, matter for capital markets in general and for fintech in particular.

25 An alternative source of funding for start-ups and SMEs could be important in Europe and in the context of CMU, as EU SMEs have experienced tight credit restrictions during the crisis because of their dependence on the traditional banking sector and absence of an integrated capital market. Recent research suggests that these forms of alternative finance provided $€ 385$ million to nearly 10,000 European businesses in the last three years and that the volume of online alternative business funding has been increasing at around 75 percent annually (figures from Cambridge Centre for Alternative Finance, 2015). The total amount of alternative business financing was calculated by combining the volume of peer-to-peer business lending, equity-based crowdfunding, invoice trading and debt-based securities platforms, plus an estimated 10 percent (for both volume and number of businesses financed) from the reward-based crowdfunding sector.

26 As the European Commission (2016) states: "crowdfunding remains to a large extent a regional or local phenomenon".

27 The European Parliament (2017) has called on the European Commission to develop a European approach to fintech.

28 Table 1 in Cermeño (2016) shows some of the substantial regulatory divergence in the EU.

29 Véron and Wolff (2015) laid out a vision of what would foster deep structural reform of European capital markets. 


\section{Issue 2: What regulatory approach to take?}

The second important issue deserving discussion is what regulatory approach should be taken. Early decisions could shape European fintech and financial intermediation for a long period. Experience suggests that regulatory decisions can have long-lasting impact on an industry when it is young, and are difficult to reverse ${ }^{30}$. It is thus important to identify the right regulatory framework early in order to allow the industry to grow and enjoy consumer trust.

Much of the current regulatory discussion is on the question of the level playing field. For example, the European Parliament calls for the "same service, same rules, same supervision". This call sounds good in theory but it is unclear what it means in practice. Much bank regulation or capital markets regulation is centred on institutions and not on services. But fintech is often an industry that offers new services or existing services with a different institutional set-up, for which the existing regulatory framework may be ill-suited. The current solution to this problem is to offer regulatory 'sandboxes' to allow supervisors and fintech actors to experiment and learn without having to apply the full set of regulation used for larger players ${ }^{31}$. While this may be a short-term solution, it is not a strategy for developing a stable and long-term regulatory vision, especially if the relevant markets are to grow significantly. Moreover, proportionality should be an important consideration in defining the regulatory and supervisory approaches to fintech firms. This also means that large and more systemic players face different scrutiny and higher requirements than smaller and less systemic players. In short, not all of fintech can be subsumed under existing capital markets regulation such as MIFID and new regulatory approaches will be needed in some segments of the markets. This in turn will raise demand for regulatory change among traditional financial intermediaries.

The regulatory debate should focus on what kind of financial system and fintech ecosystem the European Union would like to have. The regulatory challenge is to allow and encourage disruption that is desired while preventing the built-up of undesirable features in a new financial ecosystem. For example, should the system encourage lower leverage than currently and less liquidity risk? What will be the implications of blockchain-based post-trade settlement systems for liquidity of global markets? Will fintech be shaped in a way to increase financial stability? The question of what the desired end result should be is therefore crucial. The regulatory debate should also consider the impact of regulation on the ability of European fintech companies to become relevant global actors.

Putting the consumer in the centre of the public policy approach could be particularly apposite. Much of the transformation of financial intermediation through fintech will be consumer-driven in the sense that fintech's success or failure will depend on the large-scale take-up by customers. In the European context, issues such as data privacy, cybersecurity, consumer protection and operational risks will be of central importance for consumer acceptance. For example, consumers might only be ready to switch to app-based payment systems if the credibility of the system is certified early on and consumer protection is built in. The experience with the dot.com bubble in Germany shows that if households invest on the basis of misleading messages and lose money, their appetite for subsequent equity investment can be dampened for a long period. Setting high standards early to protect fintech consumers will be important for the industry. At the same time, when access to finance becomes easier, as is the aim of fintech, the consumer's capacity to understand and absorb the services provided are of great importance. Encouraging and promoting financial literacy will be essential for fintech to acquire credibility and be accepted.

30 Philippon (2016) provides the example of money market funds regulation.

31 See, for example AFM-DNB (2016). 


\section{Issue 3: Does the EU need an institution to oversee fintech?}

If the EU is to exploit fully the opportunity of fintech, it will need to put an institution in charge of the file. It is striking to observe the large number of institutions currently commenting, regulating, drafting consultations and exchanging ideas on fintech. Numerous national regulators and supervisors feel responsible for aspects of fintech. The EBA has developed a comprehensive mapping exercise of fintech in more than 24 EEA countries (EBA, 2017). The European Commission has set up an internal task force and has undertaken a public consultation on various aspects of fintech. Thus, a multitude of organisations analyse and make recommendations and a number of institutions also regulate and supervise. There are already overlaps at European level, but more importantly there is already substantial regulatory and supervisory divergence between EU countries. Deciding earlier rather than later whether or not a European market would fit the sector better would be decisive in identifying what supporting institutions should be put in place ${ }^{32}$.

A single European market for fintech would benefit from a single European institution to supervise it. To avoid a further fragmentation of the European fintech market, EU leaders could discuss which EU institutions should be in charge of supervision of fintech capital market activities. Because consumer concerns are particularly important in the context of financial services and fintech, it might be useful to give the European institution a mandate for prudential and for conduct supervision. The institution would also be in charge of monitoring the markets, and collecting and publishing data.

A natural candidate for this role would be ESMA, whose role as a conduct supervisor should be strengthened ${ }^{33}$. This would enhance the importance of the markets' supervisor by granting it authority over most aspects of the protection of investors' and savers' interests, which are crucial for fintech. Direct ESMA supervision of EU-based fintech companies and third-country fintech firms with EU operations should become the default mode for all fintech segments, because such firms are expected to have cross-border business models. In other words, starting from national supervision should be considered inefficient until proven otherwise, not the other way around. ESMA's conduct supervisory role would then also extend to fintech firms that are comparable to banks. ESMA's existing direct supervisory capacity (supervision of credit rating agencies, trade repositories and the proposal from June by the EC for CCPs) makes it a natural candidate for this enhanced role as a conduct supervisor of fintech. Scaling it up would probably require adapting ESMA's governance and funding ${ }^{34}$. On the prudential side, existing institutions such as the ECB's SSM should continue to play their role and might also increasingly become involved in fintech supervision to the extent that the respective fintech company becomes bank-like. In the short term, ESMA could also play some role as the prudential supervisor in certain fintech sub-sectors, but ideally a separation between the functions should be considered in the medium-term.

European institutions should also usefully take care of big picture issues such as data protection, data privacy, cybersecurity and competition policy concerns. In particular, fintech companies could significantly change the competitive nature of markets with access to large data and the EU's competition authority would be best placed to assess this. Standards to limit operational risks arising from cybersecurity threats and ensure data privacy are best regulated and supervised at European level if one wants to avoid fragmentation of the market.

32 Cermeño (2016) has a useful summary of the different positions of different EU and international institutions.

33 A 'twin peaks' design that distinguishes between conduct supervision and prudential supervision would reduce conflicts of interest inherent in models that combine prudential and conduct supervision. See Schoenmaker and Véron (2017).

34 See Veron (2017, page 8) for details of this argument. 


\section{Issue 4: A new 'Lamfalussy' group?}

The development of European capital markets needs strategic reflection. As already mentioned, Fintech and Brexit both pose significant strategic challenges to European capital markets but so far there has been an absence of overall strategic reflection and discourse on fintech. While there has been a lot of detailed work on specific aspects of fintech, the overall coherence of the policy debate is missing. The internal European Commission task force provides useful guidance but given the potential of fintech and techfin to profoundly disrupt markets (in parallel with the challenges arising from Brexit), a high-level reflection group would be beneficial. Such a high-level reflection group could guide the European strategic policy debate on the reshaping of Europe's financial system, including on issues beyond fintech, such as ESMA reform.

\section{References}

AFM-DNB (2016) 'More room for innovation in the financial sector. Market access, authorisations and supervision: Next steps AFM-DNB', December, available at https://www.dnb.nl/en/binaries/More\%20 room\%20for\%20innovation\%20in\%20the\%20financial\%20sector_tcm47-350715.pdf

Allard, Céline, Petya Koeva Brooks, John Bluedorn, Fabian Bornhorst, Franziska Ohnsorge, and Katharine Christopherson Puh (2013) 'Toward a Fiscal Union for the Euro Area', Staff Discussion Note 13/9, International Monetary Fund, available at https://www.imf.org/external/pubs/ft/sdn/2014/sdn1407. pdf

Bank for International Settlements (2017) 'Distributed ledger technology in payment, clearing and settlement - An analytical framework', February, available at https://www.bis.org/cpmi/publ/d157. pdf

Benzler, Marc (2017) 'European Fintech regulation - an overview', Clifford Chance, April, available at https://www.cliffordchance.com/briefings/2017/04/european_fintechregulation.html

Bergstresser, Daniel, John M. R. Chalmers and Peter Tufano (2009) 'Assessing the costs and benefits of brokers in the mutual fund industry', The Review of Financial Studies 22(10): 4129-4156

Berndsen, Ron (2016) 'If blockchain is the answer, what is the question?' speech to the Dutch Blockchain Conference, 20 June, available at https://www.dnb.nl/binaries/Speech\%20Ron\%20Berndsen_tcm46342846.pdf

BNP Paribas (2016) 'BNP Paribas Securities Services expands its blockchain platform for private stocks', press release, 19 September, available at https://group.bnpparibas/en/press-release/bnp-paribassecurities-services-expands-blockchain-platform-private-stocks

Broadbent, Ben (2016) 'Central banks and digital currencies', speech at the London School of Economics, 2 March, available at http://www.bankofengland.co.uk/publications/Pages/speeches/2016/886.aspx

Cambridge Centre for Alternative Finance (2015) Moving mainstream - The European Alternative Finance Benchmarking Report, February

Cambridge Centre for Alternative Finance (2016) Sustaining momentum - the 2nd European alternative finance industry report, September

Cermeño, Javier Sebastian (2016) 'Blockchain in financial services: Regulatory landscape and future challenges for its commercial application', Working Paper 16/20, BBVA Research

DNB (2016) ‘Technological Innovation and the Dutch Financial Sector', De Nederlandsche Bank, January, available at https://www.dnb.nl/en/binaries/Themaonderzoek\%20\%20uk_tcm47-336322.PDF

Draghi, Mario (2014) 'Keynote speech at the Eurofi Financial Forum in Milan', European Central Bank, September, available at https://www.ecb.europa.eu/press/key/date/2014/html/sp140911_1.en.html

EBA (2015) 'A Joint Commission Discussion Paper on automation in financial advice', December, available at https://www.eba.europa.eu/documents/10180/1299866/ JC+2015+080+Discussion+Paper+on+automation+in+financial+advice.pdf

EBA (2017) 'Discussion Paper on the EBA's approach to financial technology (Fintech)', August, available at https://www.eba.europa.eu/documents/10180/1919160/

EBA+Discussion+Paper+on+Fintech+\%28EBA-DP-2017-02\%29.pdf

ESMA (2015) 'Consultation on investment using virtual currency or distributed ledger technology', April, 
available at https://www.esma.europa.eu/press-news/consultations/investment-using-virtualcurrency-or-distributed-ledger-technology

ESMA (2016) 'Consultation on the Distributed Ledger Technology applied to securities markets', June, available at https://www.esma.europa.eu/press-news/consultations/consultation-distributedledger-technology-applied-securities-markets

ESMA (2017a) 'ESMA response to the Commission Consultation Paper on Fintech: A more competitive and innovative financial sector', June, available at https://www.esma.europa.eu/press-news/esmanews/esma-responds-commission-consultation-Fintech

ESMA (2017b) 'Report on the Distributed Ledger Technology Applied to Securities Markets', February, available at https://www.esma.europa.eu/sites/default/files/library/dlt_report_-_esma501121423017-285.pdf

European Commission (2001) Final Report of the Committee of Wise Men on the Regulation of European Securities Markets, available at http://ec.europa.eu/internal_market/securities/docs/lamfalussy/ wisemen/final-report-wise-men_en.pdf

European Commission (2016) 'Crowdfunding in the EU Capital Markets Union', Staff Working Document SWD (2016) 154 final, available at https://ec.europa.eu/info/publications/crowdfunding-eu-capitalmarkets-union_en

European Commission (2017) 'Communication from the commission to the European Parliament, the Council and the European Economic and Social Committee and the Committee of Regions on the Mid-Term Review of the Capital Markets Union Action Plan', COM(2017) 292 final, available at https:// ec.europa.eu/info/sites/info/files/communication-cmu-mid-term-review-june2017_en.pdf

European Parliament (2017) 'Report on Fintech: the influence of technology on the future of the financial sector', 2016/2243(INI), available at http://www.europarl.europa.eu/sides/getDoc.do?pubRef=-// EP//TEXT+REPORT+A8-2017-0176+0+DOC+XML+V0//EN

Financial Stability Board (2017) 'Financial Stability Implications from Fintech: Supervisory and Regulatory Issues that Merit Authorities' Attention', 27 June, available at http://www.fsb.org/ wp-content/uploads/R270617.pdf

Hach, Wolfgang, and Sebastian Steger (2016) 'Fintechs in Europe - Challenger and Partner', Roland Berger, November, available at https://www.rolandberger.com/en/Publications/pub_fintechs_in_ europe.html

Hileman, Garrick and Michel Rauchs (2017) Global Cryptocurrency Benchmarking Study, Cambridge Centre for Alternative Finance, April, available at https://ssrn.com/abstract=2965436

ING (2017) 'International Survey Mobile banking - the next generation', May, available at https://www. slideshare.net/ING/mobile-banking-the-next-generation

Juncker, Jean-Claude (2014) 'A New Start for Europe: My Agenda for Jobs, Growth, Fairness and Democratic Change', speech to the European Parliament, July, available at https://ec.europa.eu/ commission/publications/president-junckers-political-guidelines_en

Juniper Research (2017) 'Contactless Payments: NFC Handsets, Wearables \& Payment Cards 2017-2021', available at https://www.juniperresearch.com/press/press-releases/apple-pay-contactless-users-tonearly-double-reac

Kaya, Orçun (2017) 'Robo-advice - a true innovation in asset management', Deutsche Bank Research, August, available at https://www.dbresearch.com/PROD/DBR_INTERNET_EN-PROD/ PROD0000000000449010/Robo-advice_-_a_true_innovation_in_asset_managemen.pdf

Langfield, Sam, and Marco Pagano (2016) 'Bank bias in Europe: effects on systemic risk and growth', Economic Policy 31(52): 51-106, available at https://doi.org/10.1093/epolic/eiv019

Philippon, Thomas (2016) 'The Fintech Opportunity', CEPR Discussion Paper No. DP11409, available at https://ssrn.com/abstract=2814084

Sveriges Riksbank (2017) 'Riksbankens e-krona: 14 March 17 Project Plan', March, available at: http:// www.riksbank.se/Documents/Avdelningar/AFS/2017/Projektplan\%20e-kronan_170314_eng.pdf

Sapir, André, Dirk Schoenmaker and Nicolas Véron (2017) 'Making the best of Brexit for the EU27 financial system', Policy Brief 1/2017, Bruegel, available at http://bruegel.org/2017/02/making-thebest-of-brexit-for-the-eu27-financial-system/

Sapir, André and Guntram B. Wolff (2013) ‘The neglected side of banking union: reshaping Europe's financial system,' note presented at the informal ECOFIN, Vilnius 14 September, Bruegel, available at http://bruegel.org/2013/09/the-neglected-side-of-banking-union-reshaping-europes-financialsystem/

Schmitt, Matthias, and Martina Weber (2016) The Fintech Market in Germany, study for the Bundesfinanzministerium, October, available at http://www.bundesfinanzministerium.de/Content/ 
EN/Standardartikel/Topics/International_affairs/Articles/2016-12-13-study-fintech-market-ingermany.pdf?__blob=publicationFile\&v=2

Schoenmaker, Dirk, and Nicolas Véron (2017) 'EBA relocation should support a long-term 'twin-peaks' vision', Bruegel Blog, April available at http://bruegel.org/2017/04/eba-relocation-should-support-along-term-twin-peaks-vision/

The Economist (2017) 'The age of the appacus - In fintech, China shows the way', 25 February, available at https://www.economist.com/news/finance-and-economics/21717393-advanced-technologybackward-banks-and-soaring-wealth-make-china-leader

Véron, Nicolas (2017) 'The governance and ownership of significant euro-area banks', Policy Contribution 15/2017, Bruegel, available at http://bruegel.org/2017/05/the-governance-and-ownership-ofsignificant-euro-area-banks/

Véron, Nicolas (2017) 'Charting the next steps for the EU financial supervisory architecture', Policy Contribution 16/2017, Bruegel, available at http://bruegel.org/2017/06/charting-the-next-steps-forthe-eu-financial-supervisory-architecture/

Véron, Nicolas, and Guntram B. Wolff (2015) 'Capital Markets Union: a vision for the long term', Policy Contribution 2015/05, Bruegel, available at http://bruegel.org/2015/04/capital-markets-union-avision-for-the-long-term/

Zetzsche, Dirk, Ross P. Buckley, Douglas W. Arner and Janos N. Barberis (2017) 'From Fintech to Techfin: the Regulatory Challenges of Data-Driven Finance', Working Paper Series No. 6, EBI

\section{Annex 1}

Figure A1: Size of financial sector and financial intermediation (\% GDP]

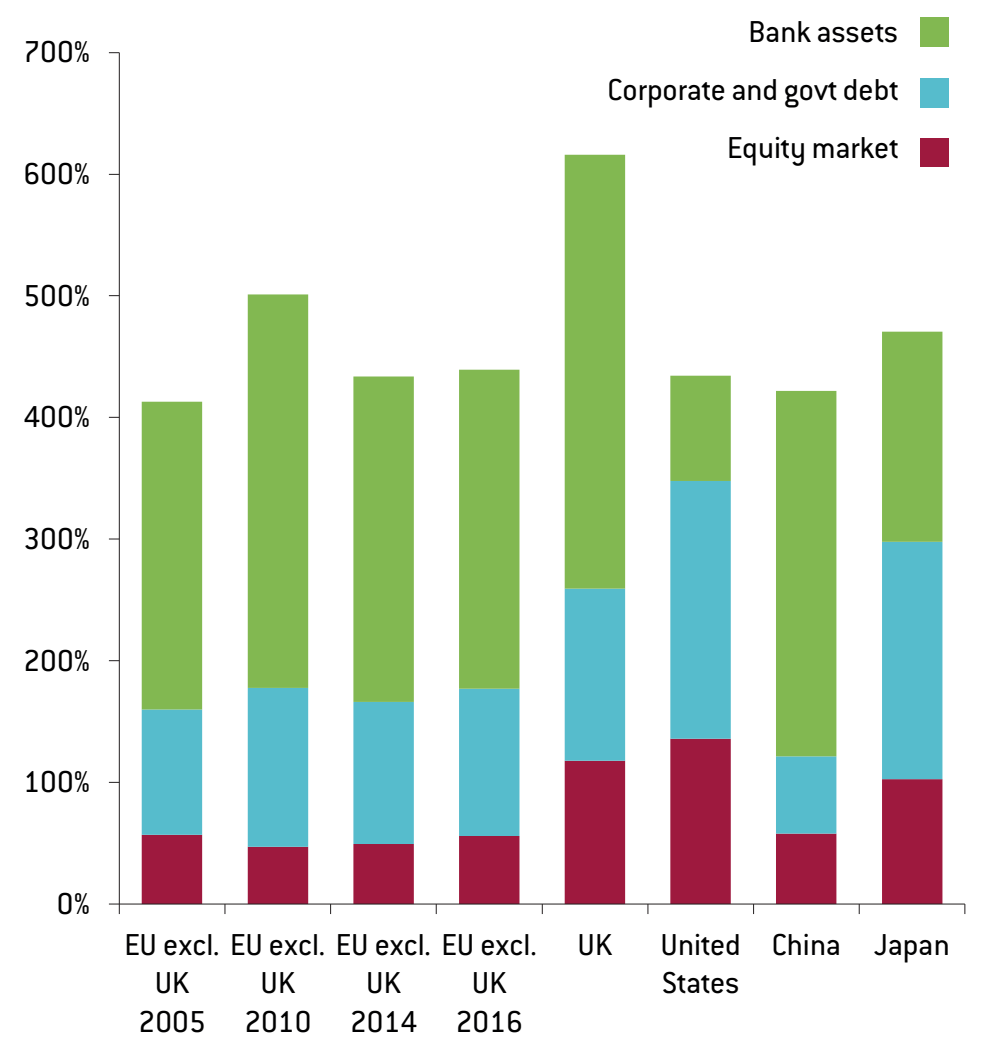

Sources: Bruegel based on IMF World Economic Outlook, Bloomberg, Association for Financial Markets in Europe (AFME), Securities Industry and Financial Markets Association (SIFMA), Asian Bonds Online, China Banking Regulatory Commission, Board of Governors of the Federal Reserve System, European Central Bank, Bank of Japan, China Statistical. Notes: For 2016 all data refer to end-2016 except EU: corporate and government debt securities (end 2015) and Japan: banking sector assets (end 2015). 
Figure A2: Financial portfolio of households in the EU and the US (in \% of total financial assets], 2015 and 2011

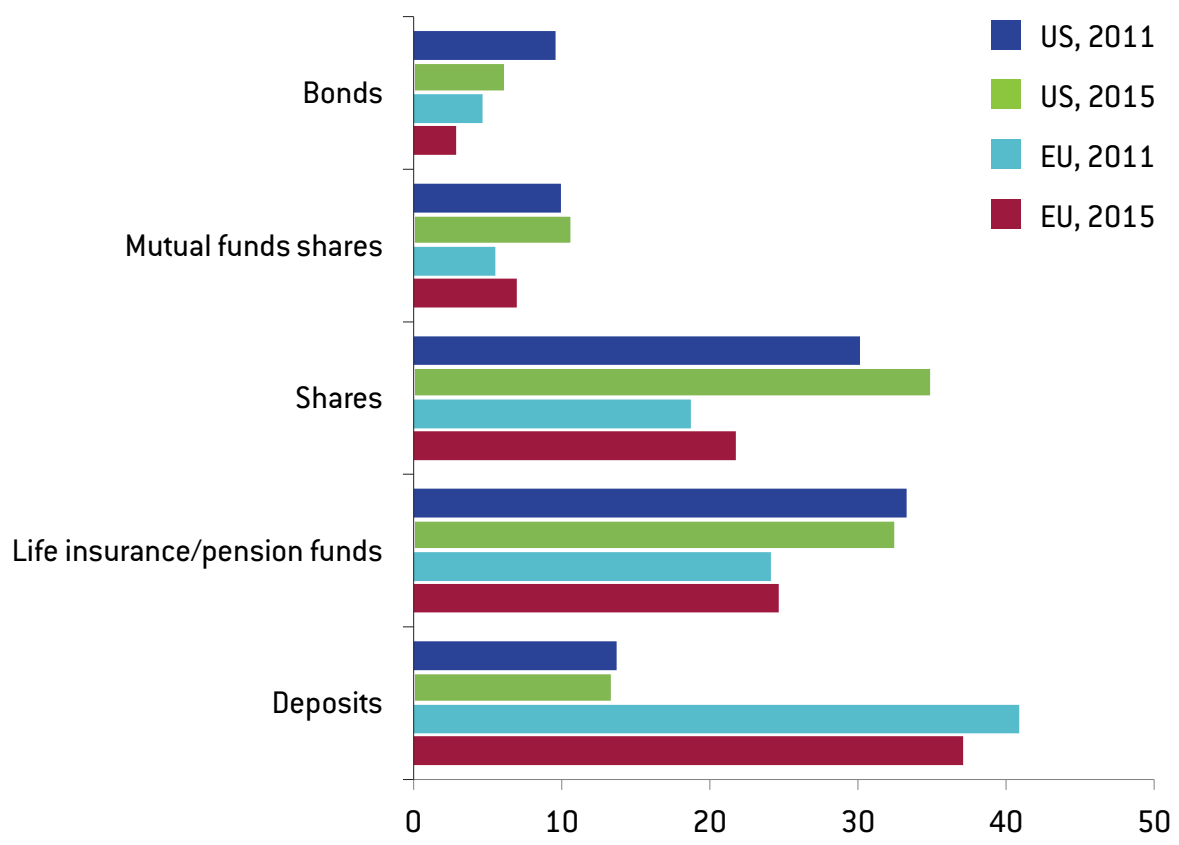

Source: $\mathrm{OECD}$, National Accounts at a Glance.

Figure A3: Composition of online alternative finance markets, 2015

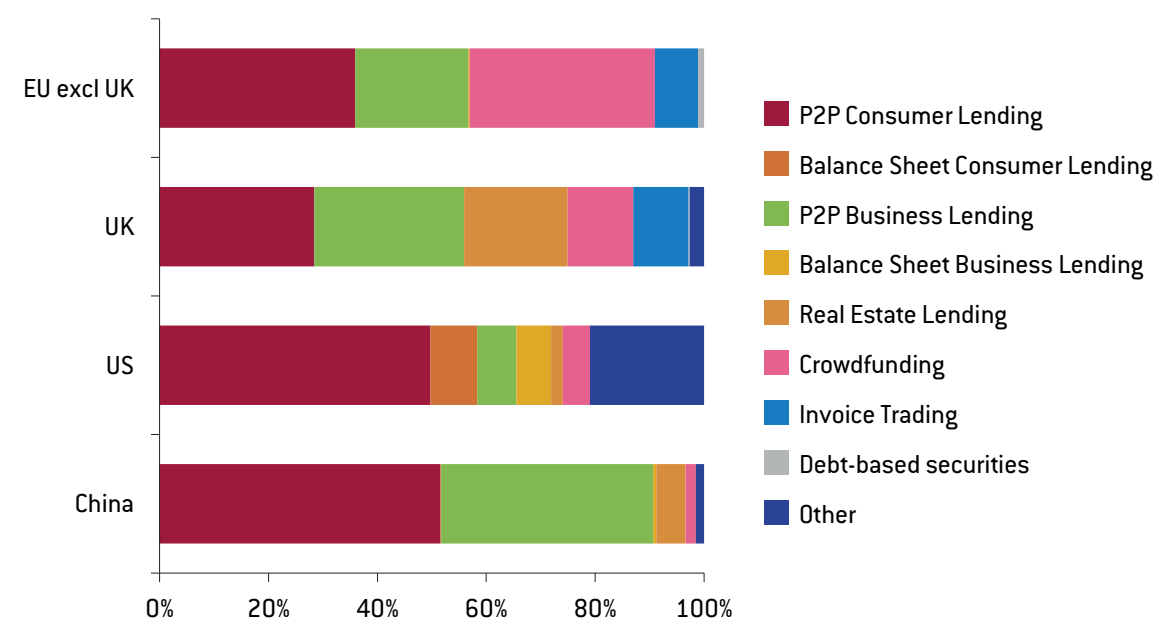

Source: Cambridge Centre for Alternative Finance.

Table A1: Cryptocurrencies' market capitalisation

\begin{tabular}{cccccc}
\hline TOTAL & \multicolumn{7}{c}{ of which: } \\
\hline Date & \$billions & Bitcoin & Ethereum & Ripple & others \\
\hline Jan.14 & 12.0 & 11 & - & 0.22 & 1.19 \\
\hline Jan.15 & 4.8 & 4 & - & 0.66 & 0.33 \\
\hline Jan.16 & 7.1 & 6 & 0.07 & 0.20 & 0.33 \\
\hline Jan.17 & 17.7 & 15 & 0.72 & 0.24 & 1.26 \\
\hline Aug.17 & 111.8 & 53 & 24.23 & 7 & 27.5 \\
\hline
\end{tabular}

Source: coinmarketcap.com, which lists 579 cryptocurrencies that have a market capitalisation above $\$ 1,000$. 


\section{Annex 2: DLT and Blockchain}

Distributed ledger technologies (DLT), of which blockchain is an example, have been generating great interest in the financial sector. The attention has spread from bitcoin to the underlying technology and its possible applications beyond the realm of cryptocurrencies.

DLT allow the secure record of data across a shared network with decentralised validation. Blockchain is a sub-category of DLT in which this network is public and the register of transactions is generated through a consensus-based process whereby all of the validated registers are cryptographically chained down to the initial 'block'. Applications include clearing, instant settlement, management of collateral and record-keeping of securities. This technology has been highlighted as having the potential to optimise processes in the existing market structure (ESMA, 2017b), namely in reducing "the traditional reliance on a central ledger managed by a trusted entity for holding and transferring funds and other financial assets" (Bank of International Settlements, 2017). Central banks have announced initiatives to understand and foster these innovations (eg Broadbent, 2016, the Dutch Central Bank's internal experiment with DNBcoin (Berndsen, 2016), the French government ruling approving the use of DLT for issuing and trading mini-bonds, already put in place by BNP Paribas (BNP Paribas, 2016) and the Swedish central bank's consideration of the use of a digital currency (Sveriges Riksbank, 2017)). Similarly, market participants have shown their interest.

The expansion of DLT faces regulatory challenges, with major differences between jurisdictions currently (Cermeño, 2016). Following two public consultations, ESMA has not identified major impediments in the EU regulatory framework that would prevent the emergence of DLT in the short term but has pressed for clarification on the legal certainty attached to DLT records (ESMA, 2015, 2016 and 2017b). There are also operational and security challenges. 